\title{
Interactive methods of assessment of knowledge on the basis of digital education on the subject "Information technology in education"
}

\author{
Jurayev Tuychi Norbutaevich \\ Department Teaching Methodology of Informatics at Karshi State University, Uzbekistan
}

\begin{abstract}
This study discusses the implementation of different interactive assessment methods through information technologies. The problems and solutions of interactive methods of assessment of knowledge using subject textbooks which are currently in practice, by electronic textbooks and manuals are shown with the examples in the article. In this study, it is expedient to use the Eclipse Crossword software which is comfortable for all users. The result of the study shows that Interactive assessment programs serve as an effective means for the teachers' limited time in the lesson in order to effectively organize, and e-learning manuals should be widely used.
\end{abstract}

Keywords: Education, Interactive, Assessment, Textbook, Program, Information.

Received: October 28, 2020

Received in Revised: November 9, 2020

Accepted: November 12, 2020

\section{Introduction}

At the present time, training the perfect generation by implementing modern pedagogical technologies in the education of young people is the task of every teacher, also, their responsibility who have been working in the education system. As every subject which has been taught, has its special place in the education system, "Informatics and information technology" subject has particular importance in the formation of outlook of students, and acquisition of knowledge of this science is closely linked to study innovative technologies and application of them to the fields.

Researchs which have been carried out on preparing textbooks and manuals on the subject of informatics and improving the efficiency of use, show that the level of acquisition of knowledge of most of the students is related to practical training, and pedagogical software tools (hereinafter, PSTs) and electronic textbooks have a special importance in the acquisition of knowledge and skills

The narrative of learning using digital networks and the use of digital media, in school context, has been based on the conceptualization of student utilization of information and communication technology, or "ICT" literacy. To wit, information technologies are seen as resources for creating, collecting, storing, and using knowledge as well as for communication and collaboration (Kozma, 2003).

As part of a data-driven style of governing, these emerging digital policy instruments prefigure the emergence of 'real-time' and 'future-tense' techniques of digital education governance. Digital database technologies mediate the generation, calculation and circulation of the data required to govern education. Conspicuously, objective statistical data are now being narrated into educational policy making, with schools and classrooms configured as 'data platforms' linked to vast global data collection programmes, and the 'reality' of education rearticulated in numerical practices that are enacted by new software developments, data companies and data analysis instruments (Lawn 2013). 
The first step in creating an interactive e-book is to project it, it includes the collection and preparation of modern teaching materials in various formats and to create teaching algorithm by the module (Brajković 2014). It is desirable to analyze the software used for preparation of PST and choose the optimal option.

Implementation of science-related information in PSTs in various formats (.pdf, .mp3, .mp4, .hd, .swf and others). Give attention to the quality of the information which has given and the permanent appeal label for the shortcomings hyper conversion. In this case, if the deficiencies are found, the PSTs creator's e-mail address will be referred for suggestions and recommendations. Professional interactivity.

In this case, the ability to self-assess in the process of teaching with PSTs education has been carried out through the graphics, text, audio, video content. Ensuring the consistency of the concepts which have been presented in the science and the implementation of a series on the basis of modules. Clear guidelines and tendencies for ensuring interdisciplinary integration. The handbook of using PSTs and the list of worldwide, local literatures. We have seen the main requirements for preparation of PST on the basis of above mentioned concepts (Tuychi 2019).

Diagnosis is to clarify all the conditions which the didactic process happens, and determine its outcomes. Diagnosis consists of monitoring, checking, evaluating, collecting statistical data, analyzing them, dynamics, identifying tendencies, and predicting future development of the phenomena (2010). Interactive questions should be focused on the interest of students to learn, developing independent thinking activities, and forming skills of using methods such as comparing, summarizing, analyzing methods. Written questions and assignments are considered the assessment means which have been created to take a written response from the trainee by the teacher (Arenas-Márquez 2010)

\section{Methods}

The main purpose of the teachers of modern informatics subject is considered to direct them to independent learning by attracting on the fields such as information technology basics, technical and software, programming, computer graphics and web design. This task is linked that it serves an important factor in determining the quality of future staff who have been teaching, and implementing information technology in all areas.

The problem in this area is that the quality of most electronic textbooks and PSTs which have been used in the education system, can not fully attract pupils or existed electronic textbooks and PSTs have not been efficiently used in the learning process in Uzbekistan. We can explain the first aspect of the problem with the development of science and technology and the lack of the PSTs of the sciences which have been made by subjects, or their spiritual outdatedness. We can explain the second factor that the skills in the use of available training materials have been not existed, or the lack of educational and technical laboratories (computers) in schools.

In this article, we will examine the different types of teaching materials in the compound of PSTs which have been prepared on the above mentioned issues by subjects and the use of different methods of assessment of knowledge in subjects in the sample of informatics and information technologies subjects in our Republic.

The use of the usual test method in PSTs prepared by subjects can decrease the motivation of students to use software and to be tired of them. We can see from the world experience, interactive assessment in software applications which have been using in learning process, 
has been carried out in different types and explanation the one information in science to the user has been carried out in a few stages.

The solution to the problem basically requires the implementation of different interactive assessment methods through information technologies, with approaching separately to each concept in the subject. The requirements which are given above, and carrying out them completely determine the efficiency coefficient of PSTs. Doing all the requirements in maximum level requires hard work from the programmer. In this article, we will try to find a solution of the issue using existed opportunities as separately approaching the professional interactive section of doing the above mentioned requirements.

We will consider the process of adding interactive crosswords to PSTs. In this case, it is expedient to use the Eclipse Crossword software which is comfortable for all users, as taking into account that the programming process is complex and requires more work. In this program, the combination of words is carried out by the program itself and can be saved prepared interactive crosswords in .html format. It is known from the pedagogical experiences that using crosswords in each lesson of PSTs increases the interest of students to the independent learning.

In this regard, the practical lessons have been taught to the students of the "Teaching methodology of informatics" department of Karshi State University by above mentioned problem and its solutions, we will discussed in detail the interactive teaching materials which they prepared with the help of their tutors, in the following.

\section{Results and Discussion}

One of the interactive crosswords which have been prepared using the subject "Informatics" of the 5th class of the general secondary school Uzbekistan, is given, the students will be able to use the materials which they have prepared, during their teaching process in the future in their pedagogical practice. Collected final materials will be united and will be formed the database of self-evaluation of PSTs for each class. The convenience of the material is considered that any operating system can support this format.
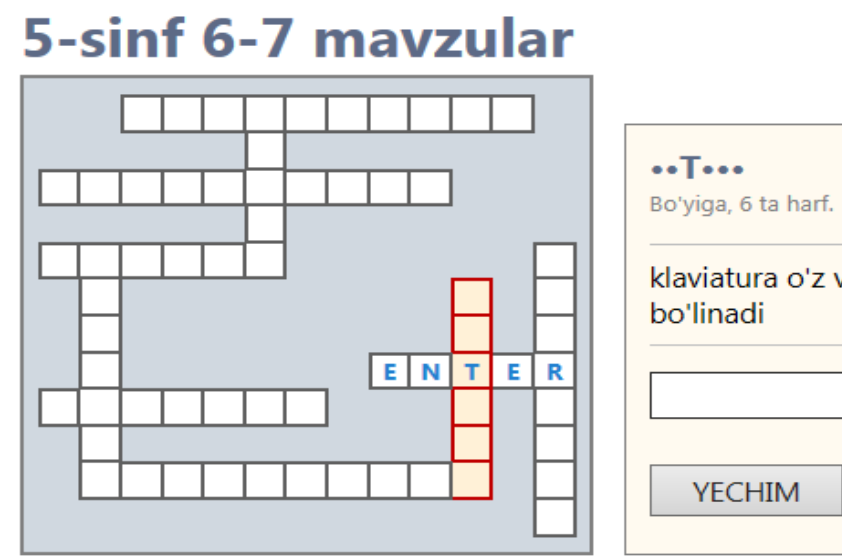

klaviatura o'z vazifalariga ko'ra necha guruhga bo'linadi

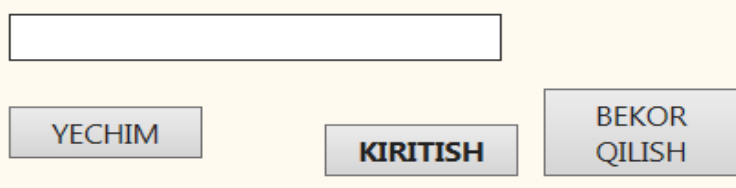

KROSSVORDNI TEKSHIRISH

Figure 1. interactive crossword

Another highly recommended software in order to enrich interactivity is the i-Spring software which has been used to perform the task for preparing various types of test, rebus, questionanswer with picture, and word-plays, prepared files can be saved in .html, .exe, .swf formats. In the following, you will see a description of the interactive assessment opportunities of the program, and we discuss some of them with examples. 
We will try to show creating processes of the following types of test questions in i-Spring program using the themes of the "Informatics" textbook of the 5th class. Students will be able to learn opportunities which they have for using all types of information when choosing questions and answers in the program. It is expedient to use more graphics that the interactive assessment process will be interesting for 5th grade students. Alternate question (Correct/incorrect): The student chooses one of two variants of the answer from this question: True or False, yes or no. This method creates the reader's ability to think rapidly.

Fikr to'g'rimi:

"Tezkor xotira-ma'lumotlarni vaqtincha kompyuter ishlashi davomida saqlaydi"

To'g'ri

Noto'g'ri

Figure 2. Alternative question

In the most frequent selection, the question is asked from the student and several answer variants are offered in order to determine the answer which they think to be correct. There are two types of questions in this type, only with one correct answer and two or more correct answers can be assessed the knowledge of students. It can be verified and evaluated the credibility of the students to their knowledge with this method.

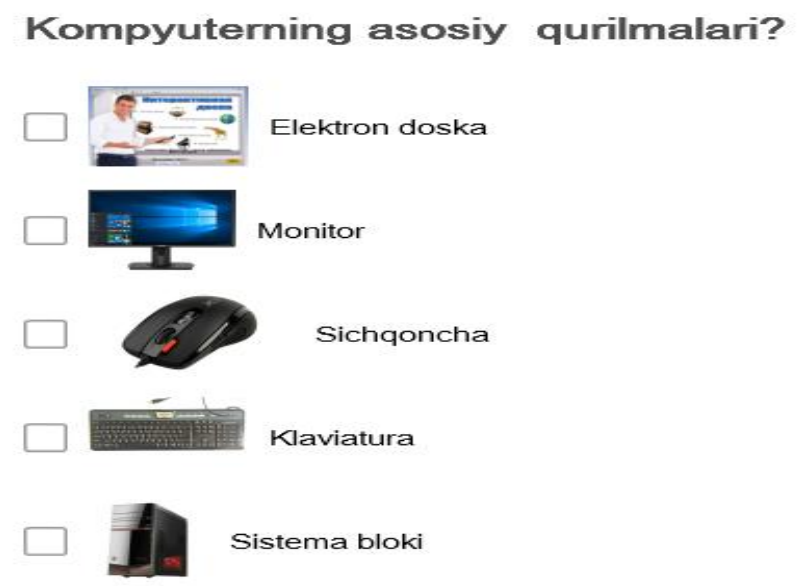

Figure 3. Multiple choice

It is similar to the question which is expressed with number, and in this case the questions and answers for them are formed on the basis of the mathematical, logical calculations.

\section{Berilgan misolni tetrada asosida ikklikda o'tkazing? $A F(16)->X(2)$}

Figure 4. Question with number

The teacher will give the list of questions and answers which are appropriate to them in order to assess with the help of the appropriate questions. In this method, it is expedient to place the 
questions on the themes in order to strengthen the knowledge of students which they have gained.

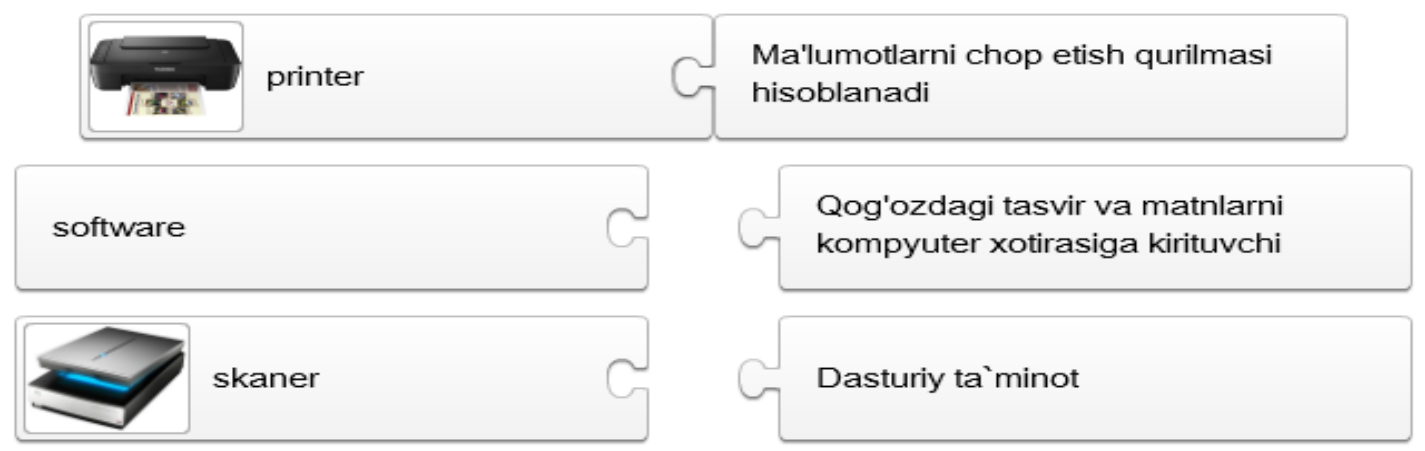

Figure 5. Question for compliance

The student will give the answer to the question himself/herself on the keyboard. The importance of this method can be explained by the formation of the ability of the student to write correct pronunciation of terms in each subject.

\section{Tashqi xotirada biror nom bilan saqlab qo'yiladigan har qanday ma'lumot bu}

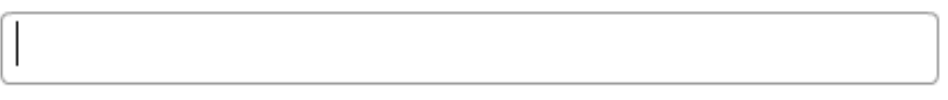

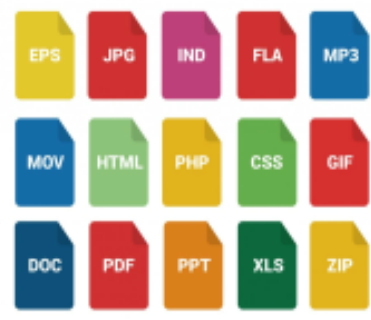

Figure 6. Question with keyword

It creates opportunity to put words in given text of the short-answer type questions to its place and to evaluate several concepts of the student in the subject through this. It is possible to put the answer to questions in these types its place with the help of the mouse. If one fraise in the answer becomes false, all answers to the question will be considered incorrect. Therefore, the teacher should take into account the relevance of the themes in choosing such questions. In this method, the student will be able to encourage considering his/her views by the knowledge of the student on subject.

\section{So'zlarni o'rniga qo'ying.}
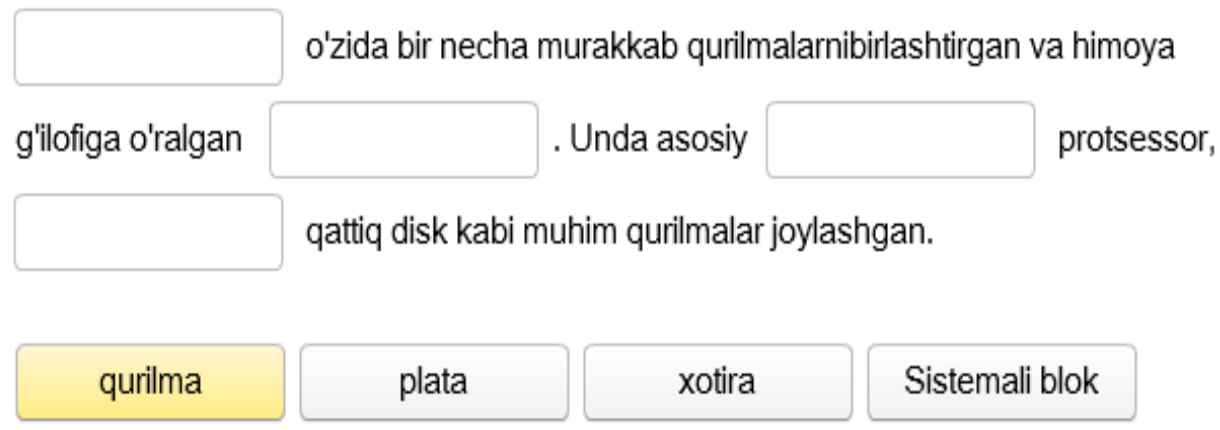

Figure 7. Order application 
The next interactive question which we will be observed, uses to evaluate knowledge of the student by sequencing information such as text, images, or audio. In fact, it is the diversity of information in subject, which actually attracts all students in the lesson.

\section{Audio savol bo'yicha tartib bilan joylashtiring}

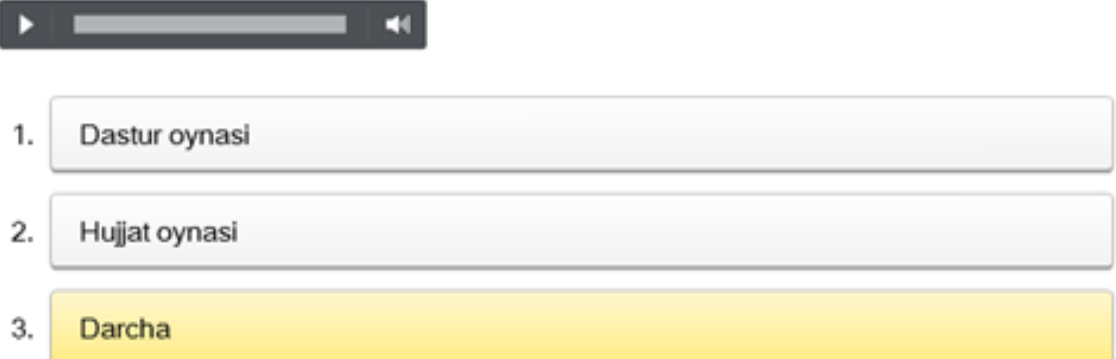

Figure 8. Question with audio order

\section{Conclusion}

In conclusion, it is expedient to ensure that future teachers will be able to work at least in the above mentioned programs, emphasizing that the solutions of the above mentioned problems serve to increase the efficiency of the e-learning materials which have been used in the lesson and the methods of knowledge diagnosis used in teaching. That's why, under the slogan "modern education is a guarantee of competitive staff", and teachers must constantly research and work. Interactive assessment programs serve as an effective means for the teachers' limited time in the lesson in order to effectively organize, and e-learning manuals should be widely used in the education because of the adequate formation of the independent learning abilities of the students. It should also announce competitions for PSTs which are prepared from subjects, such as preparing textbooks and recommend the most effective textbooks in order to use in educational institutions.

\section{References}

Brajković,M.(2014). Tools and methodologies for developing interactive electronic books (Doctoral dissertation, Universidad Complutense De Madrid).

Lawn, M. (Ed.). (2013, May). The rise of data in education systems: Collection, visualization and use. Symposium Books Ltd.

Закирова, Ф., Мухамедханов, У., Шарипов, Ш., Исянов, Р., Эсанбобоев, Ф., \& Доттоев, С. (2010). Электрон ўкув-методик мажмуалар ва таълим ресурсларини яратиш методикаси.

Arenas-Márquez, F. J., Machuca, J. A., \& Medina-López, C. (2012). Interactive learning in operations management higher education: Software design and experimental evaluation. International Journal of Operations \& Production Management, 32(12), 1395-1426.

Norbutaevich, J. T. (2020). Use Of Mobile Applications In The Process Of Teaching Information Technology. European Journal of Research and Reflection in Educational Sciences Vol. 8 No. 6.

Жўраев,Т.Н. (2019). Электрон Дарсликларда Билимни Бахолашнинг Интерфаол Усуллари («Информатика Ва Ахборот Технологиялари» Фани Мисолида). Современное образование (Узбекистан), (3 (76)). 
Otaboy, M., \& Tuychi, J. (2019, November). Handling of Transmission of Numeral Signals of Telecommunication by Means of Programmed Logical Integrated Circuits. In 2019 International Conference on Information Science and Communications Technologies (ICISCT) (pp. 1-3). IEEE.

Kozma, R. B. (2003). Technology and classroom practices: An international study. Journal of Research on Technology in Education, 36(1), 1-5. 